\title{
ROCK OUTCROPS HARBOR NATIVE PERENNIALS IN TYPE-CONVERTED COASTAL SCRUB
}

\begin{abstract}
Robert J. Steers ${ }^{1,2}$
ABSTRACT-CType-conversion of coastal scrub to exotic annual grassland has been extensive in certain parts of southern California, especially in drier inland locales. Field observations suggest that rock outcrops harbor native perennials associated with coastal scrub vegetation after conversion to exotic annual grassland has occurred. Surveys were conducted to test this observation. In addition, measures of fossorial mammal disturbance, soil depth, exotic annual plant abundance, and soil moisture were collected and used to infer potential mechanisms that may influence patterns of native and exotic vegetation. Results showed that larger outcrops are associated with more native perennial species than smaller outcrops, consistent with predictions based on species-area relationships. In addition, the edges of rock outcrops were shown to have greater native perennial species richness than the surrounding exotic annual grassland matrix. Higher soil moisture, lower soil depth, and less disturbance by Botta's pocket gopher (Thomomys bottae) were also found at the edge of rock outcrops compared to the surrounding grassland matrix. Furthermore, soil depth was positively correlated with pocket gopher disturbance and with exotic annual grass cover. Rock outcrops serve as refuge habitat for native coastal scrub perennials in areas where exotic annual grasses have become dominant. Rock outcrops may become increasingly important for conservation efforts if remaining coastal scrub vegetation continues to deteriorate.
\end{abstract}

Key words: coastal sage scrub, invasive species, richness, alternate stable states, spatial refuges, habitat heterogeneity, fossorial mammal disturbance, Thomomys bottae, plant-animal interaction, species-area relationship.

Resumen.-Ha sido extensa la conversión de matorral costero a pradera anual exótica en ciertas partes del sur de California, especialmente en localidades áridas del interior. Observaciones de campo indican que los afloramientos rocosos albergan plantas perennes nativas asociadas con vegetación de matorral costero después de la conversión a pradera anual exótica. Llevamos a cabo estudios para comprobar esta observación. También medimos la perturbación por mamíferos fosoriales, la profundidad del suelo, la abundancia de plantas anuales exóticas y la humedad del suelo para inferir los posibles mecanismos que pudieran influenciar la distribución de vegetación nativa y foránea. Los resultados mostraron que los afloramientos rocosos grandes se asocian con más especies de plantas perennes nativas que los afloramientos pequeños; esto concuerda con predicciones basadas en relaciones especies-área. Además, los bordes de los afloramientos rocosos demostraron tener mayor riqueza de especies de plantas perennes nativas que la pradera exótica circundante. También encontramos mayor humedad del suelo, menor profundidad del suelo y menos perturbación ocasionada por la tuza de Botta (Thomomys bottae) en el borde de los afloramientos rocosos en comparación con la pradera circundante. Además, la profundidad del suelo estuvo correlacionada positivamente con la perturbación por tuzas y con la cubierta de pastos anuales exóticos. En resumen, los afloramientos rocosos probaron servir de hábitat de refugio para plantas perennes nativas del matorral costero donde han llegado a dominar los pastos anuales exóticos. Los afloramientos rocosos podrían volverse cada vez más importantes para los esfuerzos de conservación si la vegetación restante del matorral costero sigue deteriorándose.

Urban and agricultural development has displaced and fragmented large expanses of coastal scrub vegetation in southern California. Remaining coastal scrub is in danger of typeconversion to exotic annual grassland (Freudenberger et al. 1987, Talluto and Suding 2008), especially in relatively arid, interior locales (Minnich and Dezzani 1998). Because coastal scrub in drier regions can exhibit an open canopy (Westman 1983), exotic annual grasses invade readily; in more mesic regions, coastal scrub usually exhibits a closed canopy, which limits the abundance of exotic annual grasses (Keeley et al. 2005a). Drier, interior coastal scrub also recovers slowly from fire, which may benefit exotic annual grass dominance (Keeley et al. $2005 \mathrm{~b}$ ). Another characteristic of interior locales is that the rate of anthropogenic nitrogen deposition can be very high (Allen et al. 1998). In addition to frequent fire, nitrogen deposition

\footnotetext{
${ }^{1}$ Department of Botany and Plant Sciences and Center for Conservation Biology, University of California, Riverside, CA 92521

2Present address: National Park Service, San Francisco Bay Area Network, Inventory and Monitoring Program, Bldg. 1063 Ft. Cronkhite, Sausalito, CA 94965. E-mail: robert_steers@nps.gov
} 
is important for promoting exotic annual grasses at the expense of native coastal scrub (Talluto and Suding 2008).

Field observations from inland southern California indicate that where coastal scrub shrublands have converted to exotic annual grassland, interspersed granitic rock outcrops are associated with more native coastal scrub perennials compared to the surrounding grassland. Therefore, rock outcrops may be important as a refuge for native coastal scrub perennials in highly altered areas. There are several features of rock outcrops that could favor native perennials. For example, while the vegetation on the surface of the rock outcrop can be susceptible to extremes in soil temperatures and water availability due to shallow soils (Houle and Phillips 1989, Benwell 2007), the edge of the outcrop can be associated with greater soil moisture due to runoff from the rock surfaces and ameliorated soil temperatures due to shading by the outcrop (Conn and Snyder-Conn 1981, Nobel et al. 1992). In addition, water stored in the fissures and crevices of weathered granite bedrock may be available to plants on rock outcrops in the dry summer season while it is not available to plants in the surrounding soil matrix (Jones and Graham 1993, Sternberg et al. 1996). This water can be important for perennial plant establishment in water-limited ecosystems (Peters et al. 2008). Rock outcrops have also been associated with lower fire intensities due to higher rock cover and fewer fuel sources on the outcrops (Fuls et al. 1992, Clarke 2002, Yates et al. 2003, Smith and Sage 2006). While rock outcrops may not affect fire frequency (Benwell 2007), lower fire intensities could favor resprouting success among coastal scrub species (Keeley et al. 2005b).

Native perennials growing among rock outcrops may be protected from fossorial-mammal disturbance (e.g., from Thomomys bottae [Eydoux and Gervais]), which can be extensive where coastal scrub has converted to exotic annual grassland (Fig. 1). Fossorial mammals are known to colonize burned or cleared shrublands (Taskey et al. 1989, Price et al. 1994); in addition, they are limited by shallow soils (Howard and Childs 1959), and in other ecosystems they restrict woody plants to rock outcrops (Cantor and Whitham 1989). Fossorial mammals can also promote exotic annual grasses (Schiffman 2007, Watts 2009), which outcompete coastal scrub shrubs for soil moisture at the seedling stage (Eliason and Allen 1997, Yelenik and Levine 2009). If soil moisture at the edge of rock outcrops is elevated (Conn and Snyder-Conn 1981), then this increase in available water may help native perennials compete with exotic annual grasses. In addition, exotic annual grass cover is positively correlated with soil depth in this region (Talluto and Suding 2008), so relatively shallow soils on or around rock outcrops can translate to lower exotic annual grass abundance and lower interference.

The primary purpose of this study was to document if rock outcrops at a nature preserve in southern California act as a refuge for native coastal scrub perennials in areas where coastal scrub has type-converted to exotic annual grassland (Temple 2000). Granitic rock outcrops were a common feature of the landscape and were interspersed among the exotic annual grassland, hereafter referred to as grassland matrix. The size of rock outcrops and the richness of perennial species per outcrop were measured. In addition, perennial species richness at the edge of rock outcrops was compared to locations within the grassland matrix to test the hypothesis that rock outcrops are more speciose than the grassland matrix (Gram et al. 2004).

The secondary purpose of this study was to investigate the relationships among fossorial mammal disturbance, soil depth, exotic annual grass abundance, and soil moisture at the edge of the rock outcrops compared to the grassland matrix. In addition, data collected on the grassland matrix were used to test the following hypotheses: (1) deeper soils have increased fossorial mammal disturbance; (2) deeper soils contain greater exotic annual grass abundance; and (3) fossorial mammal disturbance and exotic annual grass abundance are positively correlated.

\section{Methods}

\section{Study Site}

The study was conducted in Sycamore Canyon Wilderness Park, Riverside, California $\left(33.952^{\circ} \mathrm{N},-117.320^{\circ} \mathrm{W}\right)$. This area was composed of hilly terrain at an elevation of around $400 \mathrm{~m}$. Soil consisted of decomposed granite intermixed with granite boulders (NRCS 2009). Vegetation was an exotic annual grassland (i.e., grassland matrix) that had previously type-converted from coastal scrub (Minnich and Dezzani 1998, Temple 2000, Wood et al. 2006). 

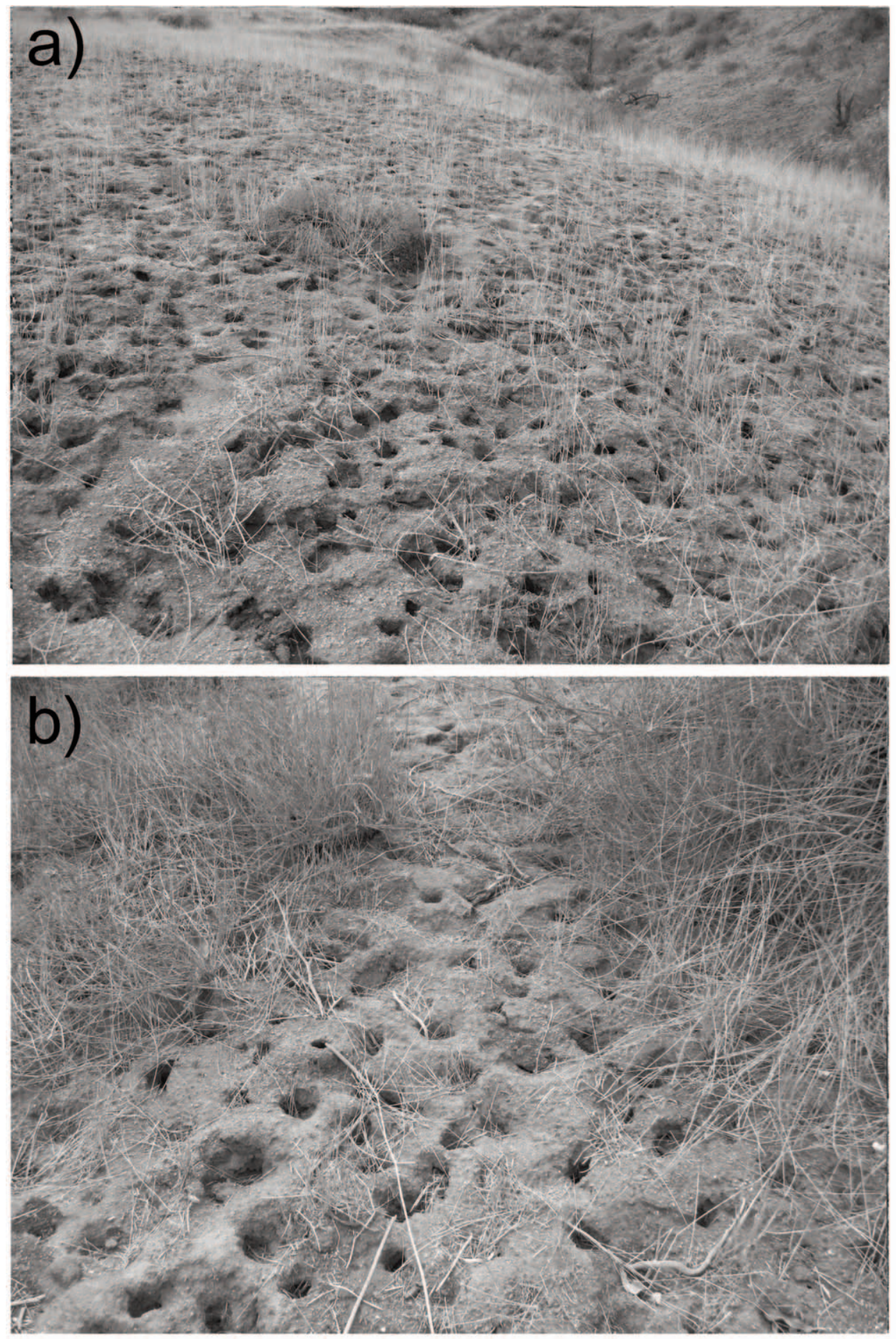

Fig. 1. Botta's pocket gopher (Thomomys bottae) disturbance in type-converted coastal scrub. The diameter of the gopher holes are about 5-7 cm. Gopher holes were made visible by the disarticulation of annual grasses during a prolonged drought. Photos were taken on 13 October 2007 near Coyote Hill, approximately $2 \mathrm{~km}$ north of the study area. 
TABLE 1. Frequency (\%) of perennial species encountered in Sycamore Canyon on rock surfaces or at the base/edge of rock outcrops $(n=18)$.

\begin{tabular}{lcc}
\hline & \multicolumn{2}{c}{ Rock outcrop microhabitat } \\
\cline { 2 - 3 } Perennial plant species & \multicolumn{2}{c}{ Edge/border (\% frequency) } \\
\hline Exotic species & 72.2 & 5.6 \\
$\quad$ Ricinus communis & & 100 \\
$\quad$ Hirschfeldia incana & & \\
Native species & 22.2 & 38.9 \\
$\quad$ Artemisia californica & 5.6 & 5.6 \\
Brickellia desertorumb & & 5.6 \\
Calystegia macrostegia & & 16.7 \\
Datura wrightii & & 16.7 \\
Encelia farinosa & 50 & 77.8 \\
Eriogonum fasciculatum & & 11.1 \\
Lessingia filaginifolia & 11.1 & 55.6 \\
Lotus scoparius & 5.6 & 5.6 \\
Marah macrocarpus & 33.3 & 38.9 \\
Melica imperfecta & & 16.7 \\
Mirabilis californica & 38.9 & 5.6 \\
Phacelia ramosissima & 11.1 & 50 \\
Salvia mellifera & & 61.1 \\
Sambucus mexicana & & \\
Scrophularia californicab & & \\
Solanum xanti & & \\
\hline
\end{tabular}

andicates that $H$. incana can also be biennial

bIndicates species restricted to rock outcrops in Sycamore Canyon (Temple 2000)

The climate of Riverside, California, is mediterranean: cool, wet winters and warm, dry summers. Because of relatively low precipitation, coastal scrub in the vicinity of Riverside typically has lower cover than scrub closer to the coast (Kirkpatrick and Hutchinson 1977, Westman 1983). Mean annual precipitation at UC Riverside is $25.3 \mathrm{~cm}$, with a mean of $24.1 \mathrm{~cm}$ occurring from October through May, which is the growing season (WRCC 2009). Precipitation in the 2005-2006 growing season was below average at $17.9 \mathrm{~cm}$. The next growing season (2006-2007) was one of the driest on record (4.2 cm precipitation; WRCC 2009), and no annual plants germinated (Steers personal observation). Precipitation during the 2007-2008 growing season was $17.5 \mathrm{~cm}$, which was still below average but was enough to support annual herbaceous growth.

\section{Rock Outcrop Species Richness}

Rock outcrops that occurred sporadically among the grassland matrix were sampled for perennial species richness in April 2008. To minimize vegetation heterogeneity due to differences between aspects, 18 rock outcrops were randomly selected and sampled from northfacing slopes only. Also, rock outcrops within $20 \mathrm{~m}$ of drainages were excluded to avoid any influences from elevated soil moisture or riparian/scrub vegetation that could occur in those drainages. Live-perennial (including biennials) species richness was measured for 2 microhabitats per rock outcrop: fissures or cracks in the granite rocks and along the edge of granite rocks that border grassland. For edge species, any plant rooted within $1.5 \mathrm{~m}$ of the rock edge was counted. This cutoff was used because plants located farther away were assumed to be outside the influence of rock outcrops (Hellmers et al. 1955). For each outcrop, length and perpendicular width were measured and the surface area was calculated based on the equation for an ellipse. Plant species nomenclature follows Hickman (1996).

\section{Vegetation and Soil Sampling in Rock Outcrops and Grassland Matrix}

In May 2008, vegetation and soil were sampled along transects starting at the edge of rock outcrops and moving into the surrounding grassland matrix (Gram et al. 2004). Three of the 18 rock outcrops previously utilized in this study were randomly chosen to be sampled. There were 6 line transects per rock outcrop, and each line transect radiated out from the center of the rock outcrop. The first transect was laid down based on a random compass 
bearing and each subsequent line transect was placed $60^{\circ}$ from the previous compass bearing. Soil and vegetation parameters-such as presence/absence of perennial and biennial species, soil depth, gopher-hole density, and cover (\%) of exotic annual grasses-were measured within $1 \times 1-m$ quadrats that were placed along each of the 6 transects starting at the edge of the rock and then at $3,6,9,12$, and up to $15 \mathrm{~m}$ away from the rock outcrop edge.

Gopher-hole density was calculated by counting the number of active or inactive burrow holes per quadrat. The holes were identified as being made by pocket gophers and not Dipodomys spp. on the basis of the following: (1) active pocket gopher mounds were observed on site, while no active Dipodomys spp. burrows were ever seen; (2) the soil was mounded up, which is not indicative of Dipodomys spp; (3) the holes went into the soil at a steep angle while holes of Dipodomys spp. go in at a shallow angle; (4) the holes did not show the sort of soil wear typical of burrows where animals go in and out often, and also lacked aboveground trails typical of Dipodomys spp.; (5) there were multiple layers of soil casts, as though animals had tunneled through previous castings, which would produce the lumpy surface; and (6) the density and extent of the holes do not suggest Dipodomys spp. typical of coastal southern California because these animals are solitary and defend separated burrow systems (Mary Price, UC Riverside, personal communication).

Soil depth was measured at 5 points per quadrat using a 0.6-cm-diameter, steel pencil rod that was tapped into the ground with a rubber mallet until penetration ceased (Eviner and Chapin 2003, Gram et al. 2004). These 5 points occurred in the center of the frame and $35.4 \mathrm{~cm}$ toward the center from each of the 4 corners of the frame. Because pocket gophers (Thomomys bottae) are limited by soil depths less than $30 \mathrm{~cm}$ (Howard and Childs 1959), soil depth was recorded for each of the 5 points as either greater than or less than $30 \mathrm{~cm}$ (Eviner and Chapin 2003). The percentage of points per quadrat where soil depth was greater than $30 \mathrm{~cm}$ was calculated and used to represent soil depth per $1 \mathrm{~m}^{2}$.

Percent volumetric water capacity (VWC) was measured on 2 November 2008 immediately after the first rain of the wet season. Measurements were taken every 10, 30, 50, 75,
$100,200,300$, and $400 \mathrm{~cm}$ away from the rock outcrop edge on both the right and left sides (facing uphill) for 4 of 18 randomly selected rock outcrops. Measurements were made using a CS620 HydroSense ${ }^{\circledR}$ System (Campbell ${ }^{\circledR}$ Scientific) with 12-cm-long probes. Samples were collected at this time and also at least $0.5 \mathrm{~m}$ away from the canopies of perennial plants to minimize the effects of live plants on the measure.

\section{Data Analyses}

The correlation between total species richness at each rock outcrop and the respective size of each rock outcrop was determined using linear regression. One-way ANOVAs with least significant difference (LSD) tests were used to compare native perennial species richness, soil depth, and gopher-hole density among the 0 , 3 , and $6 \mathrm{~m}$ distances from the edge of the 3 rock outcrops sampled.

Correlations between vegetation and soil characteristics in the grassland matrix were performed using all plot frames along the line transects that were $\geq 6 \mathrm{~m}$ from the edge of the rock outcrop. Linear regression was used to create predictive models of soil depth and gopher-hole density, soil depth and exotic annual grass cover, and gopher-hole density and exotic annual grass cover.

With VWC data from the 4 outcrops sampled, differences between the rock-outcrop edge and distances farther away were compared using one-way ANOVA and an LSD test. All statistical analyses were performed using $\mathrm{JMP}^{\circledR}$ 7.0.2 (SAS Institute, Inc.).

\section{RESUlTS}

\section{Rock Outcrop Species Richness}

Floristic surveys of the rock outcrops detected 16 native and 2 nonnative perennials (Table 1). Linear regression of rock-outcrop size and native perennial species richness (total richness based on both outcrop microhabitats) showed a positive correlation $\left(P<0.0001, \mathrm{R}^{2}\right.$ $=0.68)$. When this relationship was analyzed separately for each microhabitat, there was a weak correlation between rock-outcrop size and native-perennial richness for plants growing on fissures in the granitic rocks $\left(P<0.0518, \mathrm{R}^{2}\right.$ $=0.22$ ). The correlation was much stronger for plants growing adjacent to the grassland matrix at the edge of rock outcrops $\left(P<0.0001, \mathrm{R}^{2}=\right.$ 0.72 ). 
a) Gopher Hole Density

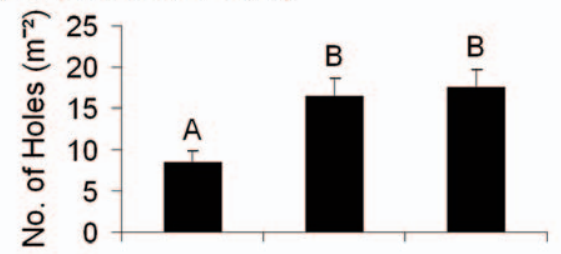

b) Soil Depth

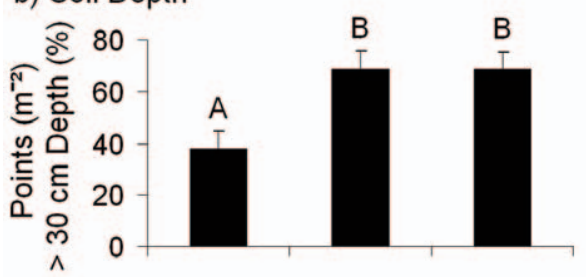

c) Invasive Annual Grass Cover

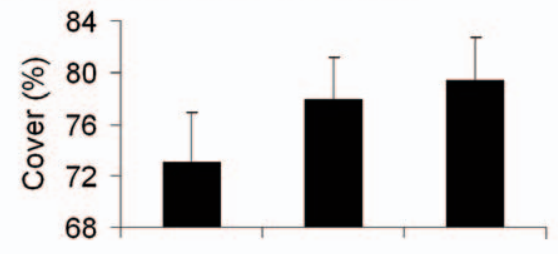

d) Perennial Plant Species Richness

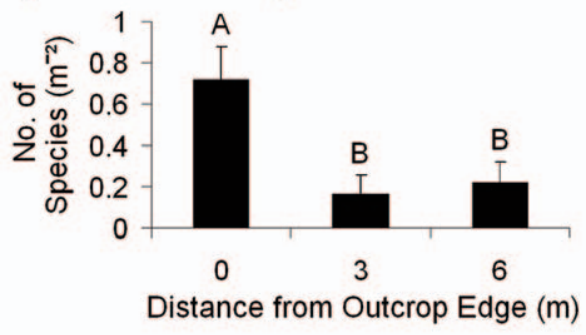

Fig. 2. Mean gopher-hole density, soil depth, exotic (invasive) annual grass cover, and native perennial species richness at 0 (edge microhabitat), 3 , and $6 \mathrm{~m}$ away from rock outcrops. Different letters indicate significant differences between the 3 distances from rock outcrops.

\section{Rock Outcrops Versus Grassland Matrix}

Soil depth, gopher-hole density, and nativeperennial species richness differed significantly between the edge of the rock outcrops and the grassland matrix $\left(F_{2,51}=6.46, P=0.0032\right.$; $F_{2,51}=6.63, P=0.0028 ; F_{2,51}=6.50, P=$ 0.0031, respectively; Fig. 2). Gopher-hole density and soil depth were lower at the edge of rock outcrops than they were at 3 or $6 \mathrm{~m}$ away from rock outcrops (Fig. 2). Conversely, nativeperennial species richness was greatest at the rock-outcrop edge (Fig. 2). No difference was

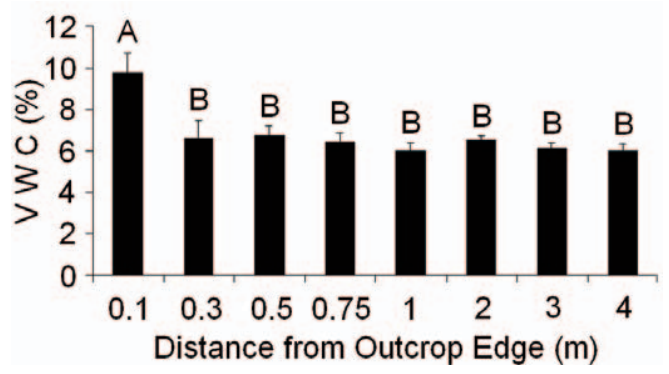

Fig. 3. Mean soil volumetric water capacity (VWC) at set distances away from the rock outcrop edge. Different letters indicate significant differences in VWC among the distances from the rock outcrop edge.

detected in cover of exotic annual grasses between the edge of rock outcrops and the grassland matrix $\left(F_{2,51}=0.82, P=0.4448\right.$; Fig. 2). Lastly, VWC was greatest for soils closest to the rock-outcrop edge (10 $\mathrm{cm}$ away) compared to soils at all other distances away from the rock outcrop $\left(F_{7,54}=5.09, P=0.0002\right.$; Fig. 3).

\section{Grassland Matrix Characteristics}

Soil in the grassland matrix was usually $>30 \mathrm{~cm}$ deep. Eighty-seven percent of all 1$\mathrm{m}^{2}$ quadrats that were $\geq 6 \mathrm{~m}$ from the edge of the rock outcrop had at least 3 out of 5 points at a depth $>30 \mathrm{~cm}$. Gopher hole density was also high throughout the grassland matrix, with a mean of 19.1 holes $\cdot \mathrm{m}^{-2}(\mathrm{SE}=1.4)$, similar to the amount $\left(19.3\right.$ holes $\left.\cdot \mathrm{m}^{-2}, \mathrm{SE}=4.1\right)$ recorded in October 2007 at another field site when bare ground was visible (Steers unpublished data). Mean exotic annual grass cover was $79.8 \%$ in the grassland matrix. The remaining coverage was mostly represented by exotic annual forbs, bare ground, and gopher holes (data not shown).

Evaluation of the relationships between soil depth, gopher-hole density, and exotic annual grass cover within the grassland matrix revealed several correlations (Fig. 4). Gopher-hole density and soil depth were positively correlated $(P$ $\left.<0.0001, \mathrm{R}^{2}=0.52\right)$ as were exotic annual grass cover and soil depth $\left(P<0.0001, \mathrm{R}^{2}=\right.$ 0.31 ). Exotic annual grass cover was also positively correlated with gopher-hole density in plots ranging in gopher-hole density from 0 to 15 gopher holes $\cdot \mathrm{m}^{-2}\left(P=0.0017, \mathrm{R}^{2}=0.49\right)$. In these plots, soil depth was relatively shallow, with only $65 \%$ of all $1-\mathrm{m}^{2}$ plot frames exhibiting at least 3 out of 5 points at a depth $>30 \mathrm{~cm}$. 
a) Soil Depth vs. Gopher Hole Density

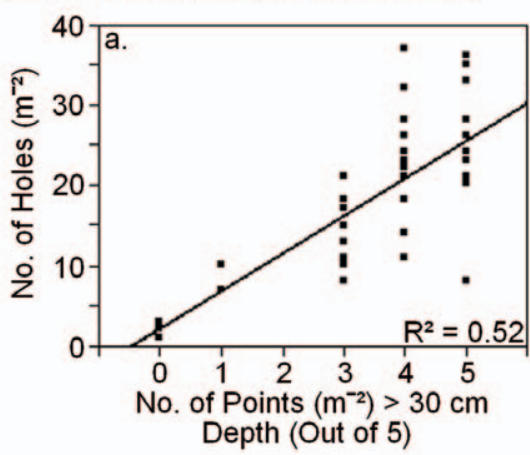

c) Gopher Hole Density vs. Invasive Annual Grass Cover

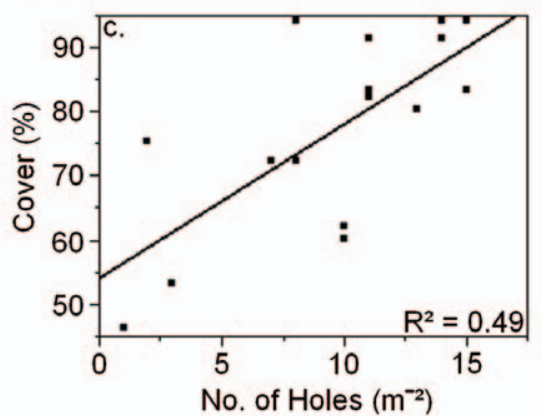

b) Soil Depth vs. Invasive Annual Grass Cover

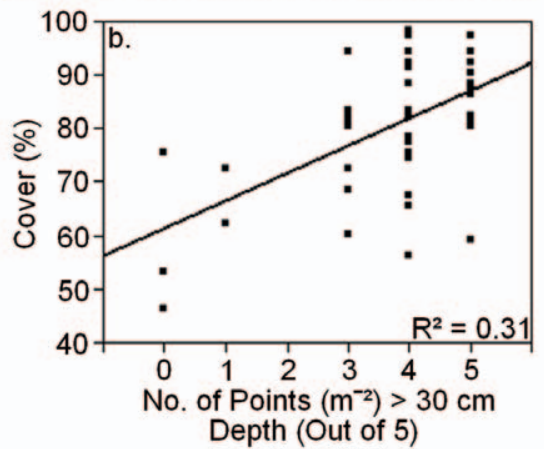

d) Gopher Hole Density vs. Invasive Annual Grass Cover

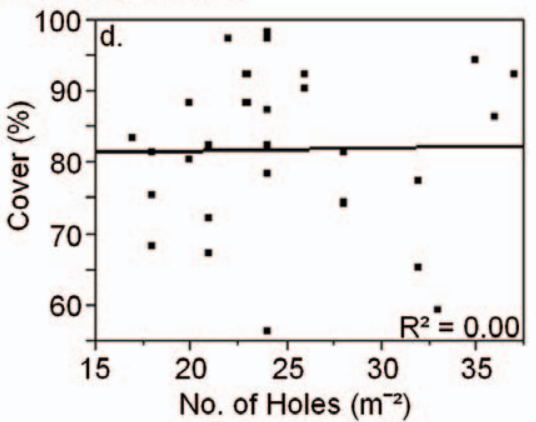

Fig. 4. Regression relationships of gopher-hole density, soil depth (number of points out of five that are $>30 \mathrm{~cm}$ depth), and exotic annual grass cover, within the grassland matrix (all plots $\geq 6 \mathrm{~m}$ from rock outcrops). Graphs $\mathrm{c}$ and $\mathrm{d}$ depict correlations between the same variables, but at different gopher-hole densities (note x-axis scale).

However, at gopher-hole densities $>15$ holes $\cdot$ $\mathrm{m}^{-2}$, there was no relationship with exotic annual grass cover $\left(P=0.8897, \mathrm{R}^{2}=0.00\right)$, and $100 \%$ of all these plot frames had at least 3 out of 5 points at a depth $>30 \mathrm{~cm}$.

\section{Discussion}

\section{Rock Outcrop Species Richness}

The majority of the perennial species encountered on the rock outcrops are not restricted to this particular habitat. Instead, of the 18 species encountered, only Brickellia desertorum and Scrophularia californica are considered obligate rock-outcrop species within the study area (Temple 2000). In general, the native perennials found on rock outcrops in this study are not rock-outcrop specialists but are coastal scrub generalists that are now mostly restricted to rock outcrops where type-conversion has occurred.

Perennial plant species richness was positively correlated with rock-outcrop size, which is consistent with the species-area relationship (Lomolino 2000). Similar results have also been recorded from rock outcrops in other ecosystems (Wyatt and Fowler 1977, Meirelles et al. 1999, Gram et al. 2004). Because the once-contiguous coastal scrub vegetation of the study area is now displaced by exotic plants, refuge habitat like rock outcrops may be increasingly important for biodiversity conservation, with larger outcrops harboring greater diversity. While rock outcrops are speciose compared to the surrounding grassland matrix, these small patches of refuge habitat seem relatively poor in terms of plant diversity and habitat value compared to the contiguous coastal scrub that once formed the matrix vegetation.

\section{Rock Outcrops Versus Grassland Matrix}

The comparison between rock-outcrop vegetation and the grassland matrix clearly shows that rock outcrops have greater species richness of native perennial plants. In general, the native perennial species associated with 
rock outcrops are competitively suppressed by exotic annual grasses (Eliason and Allen 1997) and are negatively impacted by short fire-return intervals (Zedler et al. 1983, Haidinger and Keeley 1993), both of which are indicative of this study area (Minnich and Dezzani 1998, Temple 2000). Therefore, the current scarcity of these native perennials in the grassland matrix is not particularly surprising.

While exotic annual grass cover did not differ between the edge of rock outcrops and the grassland matrix, the edge of rock outcrops exhibited lower soil depth, lower gopher-hole density, and greater soil moisture. These differences may explain several mechanisms that could promote native perennials on rock outcrops relative to the grassland matrix. First, rock outcrops may be sheltering native perennials from the adverse impact of fossorial mammals, including herbivory or soil disturbance (Schiffman 2007). For example, Cantor and Whitham (1989) showed that gopher herbivory restricted quaking aspens (Populus tremuloides) to rock outcrops even though aspens grew better in deeper soils. Second, increased soil moisture along the outcrop-edge microsite could aid native perennial seedling competition with exotic grasses (Yelenik and Levine 2009). Native coastal scrub shrubs and exotic annual grasses are highly competitive for soil moisture (Eliason and Allen 1997) and change in soil-moisture hydrology following conversion to grassland has been cited as a primary cause for the lack of native shrub success in this vicinity (Wood et al. 2006). Third, higher soil moisture at the edge of a rock outcrop, combined with lowered fire intensity due to high rock cover and less fuel biomass (Clarke 2002, Yates et al. 2003, Smith and Sage 2006), could enable greater resprouting success of native shrubs in this microhabitat. High fire severity, on the other hand, decreases resprouting (Keeley et al. 2005b). All 3 of these hypothesized mechanisms, among others, may be important for explaining the observed increase in coastal scrub species on rock outcrops relative to grassland matrix.

\section{Grassland Matrix Characteristics}

As expected, within the grassland matrix, deeper soils were associated with increased fossorial-mammal disturbance and greater exotic annual grass abundance. In addition, exotic annual grass cover exhibited a positive correlation with gopher disturbance; however, this relationship was only evident where gopherhole density was 15 holes $\cdot \mathrm{m}^{-2}$ or less. Where gopher-hole density was higher, there was no correlation. This lack of correlation may be because gopher disturbance promotes exotic grass abundance in shallow, relatively unproductive soils but does not promote it in deep soils where exotic grasses flourish regardless of additional disturbances (Talluto and Suding 2008). Alternatively, the lack of correlation between exotic annual grasses and pocket gophers in deep soils may actually be due to displacement of exotic grasses by pocket gopher disturbance. For example, it is difficult to imagine high herbaceous plant cover of any kind in an area with 37 holes . $\mathrm{m}^{-2}$, the highest density recorded in this study.

Gophers are neither abundant within nor indicative of coastal scrub vegetation (Meserve 1976, Schwilk and Keeley 1998, Chase et al. 2000). In contrast, shrub removal in coastal scrub increases the abundance of small, fossorial mammals such as kangaroo rats (Price et al. 1994). Similarly, postfire seeding of exotic grasses in chaparral can decrease native plant abundance and increase pocket gopher abundance (Taskey et al. 1989). Therefore, our observation of a high number of gopher holes in soils formerly occupied by coastal scrub strongly suggests that gophers have responded advantageously to type-conversion. It is possible that once exotic grasses replace native shrubs, gophers colonize these grassy areas and proliferate, causing further disturbances that promote exotic plants over natives (Schiffman 2007, Kyle et al. 2008, Watts 2009). Future research should make use of gopher-exclusion plots to experimentally determine the role of pocket gophers in this ecosystem.

\section{Management Implications}

An effective strategy in restoration efforts may be to use rock outcrops as nuclei from where coastal scrub can expand into the surrounding grassland matrix (Bowler 2000). Logically, restoration approaches would begin with exotic species control, which can lead to native shrub establishment (Cione et al. 2002). However, type-converted coastal scrub is highly propagule limited (Cox and Allen 2008), so additional seeding or planting of native shrubs will likely be necessary for success. Were it feasible, limiting gopher disturbance may also improve native vegetation recovery, especially when combined with other restoration treatments. 
The rock outcrops in the study area also provide important microhabitats for certain species that otherwise may not occur in this locality (Temple 2000). In general, rock outcrops increase local-scale plant diversity because they afford greater habitat heterogeneity (Ricklefs 1977). In other ecosystems, rock outcrops have consistently been noted to increase alpha diversity (Walters and Wyatt 1982, Baskin and Baskin 1988, Fuls et al. 1992, Hopper et al. 1997, Moody and Meentemeyer 2001, Gram et al. 2004, Smith and Sage 2006). Therefore, rock outcrops should be features of interest when the management of species diversity is of concern. Lastly, because climate is predicted to become more arid in southern California (Hayhoe et al. 2004), the edges of rock outcrops, where soil moisture is relatively high, may become especially important microsites for the local persistence of certain species (May et al. 2009).

\section{ACKNOWLEDGMENTS}

Comments by Edith Allen, Karen Beard, Leah Goldstein, Katharine Suding, and 2 anonymous reviewers helped me to greatly improve the final manuscript. Financial support was provided by the Department of Botany and Plant Sciences, the Center for Conservation Biology, and grants to E.B. Allen by the University of California, Integrated Pest Management (UC IPM), Exotic/Invasive Pest and Disease Research Program, and the National Science Foundation (DEB 04-21530).

\section{Literature Cited}

Allen, E.B., P.E. Padgett, A. Bytnerowicz, and R. MinNICH. 1998. Nitrogen deposition effects on coastal sage vegetation of southern California. Pages 131-139 in A. Bytnerowicz, M.J. Arbaugh, and S.L. Shilling, technical coordinators, Proceedings of the International Symposium on Air Pollution and Climate Change Effects on Forest Ecosystems. USDA Forest Service General Technical Report, PSW-GTR-166.

BASKIN, J.M., AND C.C. BASKIN. 1988. Endemism in rock outcrop plant communities of unglaciated eastern United States: an evaluation of the roles of the edaphic, genetic, and light factors. Journal of Biogeography $15: 829-840$.

BENWELL, A. 2007. Response of rock-outcrop and fringing vegetation to disturbance by fire and drought. Australian Journal of Botany 55:736-748.

BowLER, P.A. 2000. Ecological restoration of coastal sage scrub and its potential role in habitat conservation plans. Environmental Management 26:S85-S96.

CANTOR, L.F., AND T.G. WhithaM. 1989. Importance of belowground herbivory: pocket gophers may limit aspen to rock outcrop refugia. Ecology 70:962-970.
Chase, M.K., W.B. Kristan III, A.J. Lynam, M.V. Price, AND J.T. Rotenberry. 2000. Single species as indicators of species richness and composition in California coastal sage scrub birds and small mammals. Conservation Biology 14:474-487.

Cione, N.K., P.E. Padgett, and E.B. Allen. 2002. Restoration of a native shrubland impacted by exotic grasses, frequent fire, and nitrogen deposition in southern California. Restoration Ecology 10:376-384.

Clarke, P.J. 2002. Habitat insularity and fire response traits: evidence from a sclerophyll archipelago. Oecologia 132:582-591.

Conn, J.S., AND E.K. Snyder-Conn. 1981. The relationship of the rock outcrop microhabitat to germination, water relations, and phenology of Erythrina flabelliformis (Fabaceae) in southern Arizona. Southwestern Naturalist 25:443-451.

Cox, R.D., And E.B. Allen. 2008. Composition of soil seed banks in southern California coastal sage scrub and adjacent exotic grassland. Plant Ecology 198: $37-46$.

ELIASON, S.A., AND E.B. AlLEN. 1997. Exotic grass competition in suppressing native shrubland re-establishment. Restoration Ecology 5:245-255.

EvineR, V.T., AND F.S. ChaPIN III. 2003. Gopher-plantfungal interactions affect establishment of an invasive grass. Ecology 84:120-128.

Freudenberger, D.O., B.E. Fish, and J.E. Keeley. 1987. Distribution and stability of grasslands in the Los Angeles Basin. Bulletin of the Southern California Academy of Science 86:13-26.

Fuls, E.R., G.J. BRedenkamp, and N. van Rooyen. 1992. Plant communities of the rocky outcrops of the northern Orange Free State, South Africa. Vegetatio 103: 79-92.

Gram, W.K., E.T. Borer, K.L. Cottingham, E.W. SeaBLOOM, V.L. BOUChER, L. GoldWATER, F. MiChELI, B.E. Kendall, AND R.S. Burton. 2004. Distribution of plants in a California serpentine grassland: are rocky hummocks spatial refuges for native species? Plant Ecology 172:159-171.

Haidinger, T.L., AND J.E. KeELEY. 1993. Role of high fire frequency in destruction of mixed chaparral. Madroño 40:141-147.

Hayhoe, K., D. Cayan, C.B. Field, P.C. Frumhoff, E.P. MaUrer, N.L. Miller, S.C. Moser, S.H. SchNeider, K.N. Cahill, E.E. Cleland, ET AL. 2004. Emissions pathways, climate change, and impacts on California. Proceedings of the National Academy of Sciences 101:12422-12427.

Hellmers, H., J.S. Horton, G. Juhren, and J. O’Keefe. 1955. Root systems of some chaparral plants in southern California. Ecology 36:667-678

Hickman, J.C. 1996. The Jepson manual: higher plants of California. University of California Press, Berkeley, CA. 1400 pp.

Hopper, S.D., A.P. BRown, and N.G. Marchant. 1997. Plants of Western Australian granite outcrops. Journal of the Royal Society of Western Australia 80:141-158.

Houle, G., AND D.L. PHILLIPS. 1989. Seasonal variation and annual fluctuation in granite outcrop plant communities. Vegetatio 80:23-35.

HowaRD, W.E., AND H.E. CHILDS. 1959. Ecology of pocket gophers with emphasis on Thomomys bottae mewa. Hilgardia 29:277-358.

Jones, D.P., AND R.C. Graham. 1993. Water-holding characteristics of weathered granitic rock in chaparral and 
forest ecosystems. Soil Science Society of America Journal 57:256-261.

Keeley, J.E., M. Baer-Keeley, and C.J. Fotheringham. 2005a. Alien plant dynamics following fire in Mediterranean-climate California shrublands. Ecological Applications 15:2109-2125.

KeELey, J.E., C.J. Fotheringham, and M. Baer-Keeley. 2005b. Determinates of post-fire recovery and succession in Mediterranean-climate shrublands of California. Ecological Applications 15:1515-1534.

KirKPatrick, J.B., and C.F. Hutchinson. 1977. The community composition of Californian coastal sage scrub. Vegetatio 35:21-33.

Kyle, G.P., A. Kulmatiski, and K.H. Beard. 2008. Influence of pocket gopher mounds on nonnative plant establishment in a shrubsteppe ecosystem. Western North American Naturalist 68:374-381.

LOMOLINO, M.V. 2000. Ecology's most general, yet protean pattern: the species-area relationship. Journal of Biogeography 27:17-26.

May, M.R., M.C. Provance, A.C. Sanders, N.C. EllSTRAND, AND J. Ross-IbarRa. 2009. A Pleistocene clone of Palmer's oak persisting in southern California. PLoS ONE 4:e8346. doi:10.1371/journal.pone.0008346

Meirelles, S.T., V.R. PivelLo, and C.A. Joly. 1999. The vegetation of granite rock outcrops in Rio de Janeiro, Brazil, and the need for its protection. Environmental Conservation 26:10-20.

Meserve, P.L. 1976. Food relationships of a rodent fauna in a California coastal sage scrub community. Journal of Mammalogy 57:300-319.

Minnich, R.A., AND R.J. DeZZani. 1998. Historical decline of coastal sage scrub in the Riverside-Perris Plain, California. Western Birds 29:366-391.

Moody, A., AND R.K. MeEnTEMEYER. 2001. Environmental factors influencing spatial patterns of shrub diversity in chaparral, Santa Ynez Mountains, California. Journal of Vegetation Science 12:41-52.

[NRCS] Natural Resources Conservation Service. 2009. Web soil survey. Available from: http://websoilsurvey .nrcs.usda.gov

Nobel, P.S., P. Miller, and E. Gram. 1992. Influence of rocks on soil temperature, soil water potential and rooting patterns for desert succulents. Oecologia 92:90-96.

Peters, E.M., C. Martorell, and E. Ezcurra. 2008. Nurse rocks are more important than nurse plants in determining the distribution and establishment of globosa cacti (Mammillaria) in the Tehuacán Valley, Mexico. Journal of Arid Environments 72:593-601.

Price, M.V., R.L. GoldingaY, S. SZYChowsKi, AND N.M. WASER. 1994. Managing habitat for the endangered Stephen's kangaroo rat (Dipodomys stephensi): effects of shrub removal. American Midland Naturalist 131: 9-16.

RICKLEFS, R.E. 1977. Environmental heterogeneity and plant species diversity: a hypothesis. American Naturalist 111:376-381.

Schiffman, P.M. 2007. Ecology of native animals in California grasslands. Pages 180-190 in M.R. Stromberg, J.D. Corbin, and C.M. D'Antonio, editors, California grasslands: ecology and management. University of California Press, Berkeley, CA.
SChwilk, D.W., AND J.E. KeELEY. 1998. Rodent populations after a large wildfire in California chaparral and coastal sage scrub. Southwestern Naturalist 43: $480-483$.

SMITH, R.S., AND L.W. SAGE. 2006. Vegetation on and around granite rock outcrops in the Wellington National Park. Conservation Science Western Australia 5:259268.

Sternberg, P.D., M.A. Anderson, R.C. Graham, J.L. BEYERS, AND K.R. Tice. 1996. Root distribution and seasonal water status in weathered granitic bedrock under chaparral. Geoderma 72:89-98.

Talluto, M.V., AND K.N. Suding. 2008. Historical change in coastal sage scrub in southern California, USA in relation to fire frequency and air pollution. Landscape Ecology 23:803-815.

Taskey, R.D., C.L. Curtis, and J. Stone. 1989. Wildfire, ryegrass seeding, and watershed rehabilitation. Pages 115-124 in N.H. Berg, technical coordinator, Proceedings of the Symposium on Fire and Watershed Management. General Technical Report PSW-109, USDA Forest Service, Sacramento, CA.

Temple, P.J. 2000. Plants of Sycamore Canyon Park, Riverside, California. Crossosoma 25:45-70.

WaLters, T.W., AND R. WyatT. 1982. The vascular flora of granite outcrops in the central mineral region of Texas. Bulletin of the Torrey Botanical Club 109:344-364.

WATTS, S.M. 2009. Pocket gophers and the invasion and restoration of native bunchgrass communities. Restoration Ecology. doi:10.1111/j.1526-100X.2009.00518.x

[WrCC] Western Regional Climate Center. 2009. Historical climate summary for the UC Riverside Citrus Experiment Station (047473) from 7/1/1948 to 12/31/2007. Available from: http://www.wrcc.dri.edu/ cgi-bin/cliMAIN.pl?ca7473WESTMAN, W.E. 1983. Xeric Mediterranean-type shrubland associations of Alta and Baja California and community/continuum debate. Vegetatio 52:3-19.

Wood, Y.A., T. Meixner, P.J. Shouse, and E.B. Allen. 2006. Altered ecohydrologic response drives native shrub loss under conditions of elevated nitrogen deposition. Journal of Environmental Quality 35:76-92.

WyatT, R., AND N. Fowler. 1977. The vascular flora and vegetation of the North Carolina granite outcrops. Bulletin of the Torrey Botanical Club 104:245-253.

Yates, C.J., S.D. Hopper, A. Brown, and S. van Leeuwen. 2003. Impact of two wildfires on endemic granite outcrop vegetation in Western Australia. Journal of Vegetation Science 14:185-194.

YeLENIK, S.G., AND J.M. Levine. 2009. Processes limiting native shrub recovery in exotic grasslands after nonnative herbivore removal. Restoration Ecology. doi: 10.1111/j.1526-100X.2009.00598.x

Zedler, P.H., C.R. Gautier, and G.S. McMaster. 1983. Vegetation change in response to extreme events: the effect of a short interval between fires in California chaparral and coastal scrub. Ecology 64:809818.

Received 6 July 2009

Accepted 14 July 2010 